\title{
SILENCES AND VOICES OF MEDITERRANEAN CROSSINGS: (INTER)SUBJECTIVITY AND EMPATHY AS RESEARCH PRACTICE
}

GABRIELE PROGLIO

Universidade de Coimbra

ABSTRACT This essay is dedicated to analyze the role of intersubjectivity in my oral research project with migrant people coming from or culturally connected to the Horn of Africa. In the past 5 years, I have interviewed people coming from Somalia, Ethiopia and Eritrea to Europe, men and women, differently aged. My goal was to study the postcolonial and diasporic memory, the journeys from the Horn of Africa to Europe, the relationship of migrant people with friends and parents in other parts of the world. In this paper, I point out my oral history research approach and the relevance of empathy during the interviews.

Keywords: Oral memory. Intersubjectivity. Postcolonial. Mediterranean crossings.

RESUMO SILÊNCIOS E VOZES DO MEDITERRÂNEO:

\section{(INTER)SUBJETIVIDADE E EMPATIA COMO PRÁTICA DE PESQUISA}

Este ensaio é dedicado a analisar o papel da intersubjetividade em meu projeto de pesquisa oral com migrantes culturalmente ligados ao Nordeste da África. Nos últimos cinco anos, entrevistei várias pessoas provenientes de Somália, Etiópia e Eritréia para a Europa, homens e mulheres, de idades diferentes. Meu objetivo era estudar a memória pós-colonial e da diáspora, as viagens do Corno de África para a Europa, a relação das pessoas migrantes com amigos e parentes em outras partes do mundo. Neste texto, exponho a minha abordagem da pesquisa em história oral e a relevância da empatia no trabalho de entrevista com migrantes.

Palavras-chave: Memória oral. Intersubjetividade. Pós-colonial. Travessias do Mediterrâneo. 


\section{RESUMEN SILENCIOS Y VOCES DE LOS MEDITERRÁNEOS: (INTER)SUBJETIVIDAD Y EMPATÍA COMO PRÁCTICA DE INVESTIGACIÓN}

Este ensayo está dedicado a analizar el papel de la intersubjetividad en mi proyecto de investigación oral con migrantes que vienen o están culturalmente conectados con el Cuerno de África. En los últimos 5 años, entrevisté a varias personas procedentes de Somalia, Etiopía y Eritrea a Europa, hombres y mujeres, de edades diferentes. La memoria poscolonial y diaspórica, los viajes del Cuerno de África a Europa, el otro lado del mundo. En este escrito, me gustaría señalar mi enfoque en la investigación de historia oral y la relevancia de la empatía durante las entrevistas.

Palabras clave: Memoria oral. Intersubjetividad. Poscolonial. Cruces del Mediterráneo.

Who knows? not me We never lost control You're face to face With the Man who Sold the World David Bowie - The Man Who Sold the World

Where there were deserts I saw fountains like cream the waters rise and we strolled there together

Patti Smith, 1988 - People Have the Power

I remember their faces, gazes lost in the void. Frequently, I think about specific details of our meetings: a young Eritrean woman in the act of beating her shoulder, repeatedly touching a tattoo representing Africa; the urban space around us, an unexpected framework where stories take place - sometimes, the main Italian downtown tourist areas, in other cases, desolate peripheral areas, forsaken buildings and soiled gardens; the silence after a question about the journey from Somalia to Libya. These memories are fixed in my mind. I would like to pay attention to their form, how they appear in the act of remembering. They are fragments, parts of a whole - the oral tale whose borders, in contrast to the focus on a single part, become blurry and undefined. At the same time, they have a self-autonomy of meaning: they could describe much more than the expression of an answer, a doubt, a feeling. They can disclose to the eyes of the interviewer a world made of beliefs and fears, dreams and anxieties, phobias and hopes; they can bring to mind intuitions about the person's past and its repercussions in the present, such as the need for a common identity and a sturdy imagined collective history able to justify and explain unintelligible and 
hard-to-approach happenings such as ethnic genocide, civil war, the disappearance of a friend because of the regime, a recurring widespread act of violence such as infibulation and female genital mutilation.

According to Benjamin's theory, one can grasp the meaning of history though the passing of a single moment. In Passages (1999), the idea of the 'dialectical image' is opposed to the epoche and is connected with the ongoing relationship with the 'other-than-self'. An ontology of the image is not possible in the absence of a relationship. On the contrary, the dialectical image gathers past, present and future together. Benjamin stated that 'an image is that in which the Then (das Gewesene) and the Now (das Jetzt) come into a constellation like a flash of lightning'. In other words, 'image is dialectics at a standstill' (BENJAMIN, 1999, p. 492). The fragments of memory listed above seem similar to such dialectical images. They carry me back to the time of my meetings with people who fled to Europe from wars, famine and civil conflicts - people coming from the former colonies in the Horn of Africa with kinds of different citizenship status: illegals, asylum seekers, refugees. At the same time, they are vectors of meaning elaborated when I, as interviewer, met each interviewee. They are also portions of contexts of sense elaborated where the public space intertwines with the private sphere for people who share common beliefs and memories, experiences and cultural contexts. Usually, they are defined simply as 'migrants', or with a plural term (refugees, illegals, etc.) which highlights their mobility to Europe and denies every form of self-subjectivity. Etienne Balibar associates this human condition with that of an 'alien', implying a revision of the status of human beings and their rights in such conditions (BALIBAR, 2004). According to Sandro Mezzadra's analysis, the extension of 'models of war' alongside the Schengen borders creates contradictory effects of the violent security policies waged 'in the name of Europe' (Mezzadra 2001). For example, flows of migrants towards Europe are needed to produce new forms of the old 'capitalist reverse army'. These people, then, inhabit a similar public space; their collocation in the European social context is similar. In this public space, like a new borderless ghetto, voices from Ethiopia, Eritrea and Somalia shared multiple experiences related to their arrival in Europe, and rethinking their past life in Africa.

This essay will raise theoretical questions, which are relevant for both autobiographical studies and oral history, about the role of intersubjectivity during and after the collection of interviews with people who illegally crossed the Mediterranean Sea from Libya to Italy. Some of these people applied for acceptance as refugees or were asylum seekers in Lampedusa, the first European island or, as artist Mimmo Paladino called his installation, the 'gate of Europe'. My aim is to focus attention on processes of intersubjectivity production in both sides: the interviewer and the interviewees. From another perspective, concerning the proposal of a new (not exclusively) European geography, this meeting between two people in the production of a new narrative during the interview could be a sign of a dialogic space for representation despite the proliferation of borders and the militarization of frontiers. This possibility shows the creation of a space where new meanings, languages and beliefs are constantly invented: this symbolic and real space is changing the profile of Europe, reinventing its cultural and social geography.

This paper is divided in three parts: after a brief introduction of my past research project, the first part will deal with the debate on intersubjectivity in the social sciences and its 
impacts on (auto)biographical research and oral history. The second part will examine the problematization of silence in some oral tales collected during my fieldwork in Italy. The third part will deal with the case of a woman, Angela/Malaika, who used her narrative to affirm her way of being 'out of place' in Italy and Europe. In the conclusion, I will present my considerations on the idea of empathy as a way of reinventing the world from an inclusive, collective perspective concretely rooted in the research process with migrants and refugees.

\section{A view of the intersubjectivity debate in the field of oral history}

Oral history research as a specific way to do history emerged in the 1940s and 1950s in Europe with the purpose of developing a new theoretical perspective: many scholars were interested in collecting 'history from below' (PERKIN, 1976, p. 132) or 'people's history' (SAMUEL, 1971, p. 19-22). The aim was to collect stories from people whose voices had not been heard in the public sphere, or to provide a voice for those who would otherwise be "hidden from history' (ROWBOTHAM, 1973). This theoretical approach was influenced by wider debates in social history, labour history and women's history. Many of the oral historians who influenced the debate at that time came from political groups and cultural contexts that were directly involved in restarting a discussion about power relations both inside and outside the academic world. The epistemology of oral history was a laboratory where new forms of doing history combined the attempt to analyse the role of hegemonic powers in Western societies with the will to find ways to tell the stories of hidden, silenced and invisibilized subjects and subjectivities.

In particular, the idea of intersubjectivity a word that had previously been used in the social sciences, mainly psychology and sociology - became relevant to the scientific debate about oral memory and narratives applied to the study of labour (Asa Briggs, Elizabeth Roberts, Raphael Samuel, John Saville), ethnic groups (Elizabeth Thomas-Hope, Donald Hinds, Poina Werbner, Harry Goulbourne), LGBT communities (BRIGHTON OURSTORY, 1992; BROWN 2001; JENNINGS, 2004; LOMAS, 2007). Alex Haley's analysis of past and present black stories and subjectivities, for example, showed how the line of colour continued throughout the history of the United States (HALEY, 1965). According to Paul Thompson, 'oral history certainly can be a means for transforming both the content and the purpose of history. It can be used to change the focus of history itself, and open up new areas of inquiry' (Thompson $1988,3)$. It can break down barriers between teachers and students, between generations, and between educational institutions and the world outside. Ronald J. Grele and Luisa Passerini, among other scholars, have pointed out the methodological and theoretical implications of oral history in this sense (GRELE, 1985; LAMONT, 1998; PASSERINI, 1979 a and b). Michael Frisch, in his turn, introduced the key concept of 'shared authority', shifting the focus from people merely involved in the role of consumers, to subjects able to act directly in the process of doing history. In his opinion, 'A Shared Authority suggests something that is that in the nature of oral and public history, we are not the sole interpreters. Rather, the interpretive and meaning-making process is in fact shared by definition' (FRISCH, 1991). In an essay on women's oral history written as a dialogue, Susan Armitage and Sherna Berger Gluck formulated an interesting reflection in this regard: in their opinion, the 'relationship between interviewer and narrator cannot be captured in simplistic assumptions about “insider-ness"' (ARMITAGE and BERGER GLUCK, 
1998, p. 4). Furthermore, the realization that any oral history narrative is only a partial history also leads to the recognition 'that each interviewer will get different partial truths, given her or his positionality' (ARMITAGE and BERGER GLUCK, 1998, p. 6). That means that oral history is relational and eminently intersubjective.

In an essay that appeared in the end of the 1990s, Alistair Thomson summarized the criticisms of oral history, which classical 'documentary historians' accused of moving from the study of history to myth. In that article, Thomson focused on the attempt to question the 'distortions' of memory and to see 'the particularities of oral history' as strengths rather than weaknesses (THOMSON, 1999, p. 292). Oral historians such as Luisa Passerini, Alessandro Portelli, Joan Sangster, and Elizabeth Lapovsky Kennedy, among others, began to imagine more sophisticated ways of problematizing the use of memory. All these contributions were characterized by the attempt to shift the attention from the subject to the subjectivity. In particular, Luisa Passerini affirmed: "the subject cannot receive representations without creating new ones, in other words, it cannot communicate without contributing to this multiplicity" (2003, p. 27).

An 'interview' is the usual name given to the meeting of an interviewer with an interviewee (also called a respondent or informant), with an exchange of questions and answers. This is an external representation of a complex cultural process; a rough and unrefined way of pinpointing roles and borders in order to establish, beyond a doubt, who is entitled to ask a question and who has to reply. This approach highlights the idea prevalent in the social sciences about the central position of the researcher in the interpretation of a given phenomenon and posits a 'partition' separating the researcher from the subject who is interviewed. When we adopt the intersubjective gaze, what we call an 'interview' is created by two people, both of whose voices and subjectivities are equally important. Subjectivity means more than a simple positionality characterizing a person, which is difficult to reset and nullify in the first part of a study dedicated to the 'construction' of the fieldwork, as it is a vast cultural system of references made by experiences, education, beliefs, imagination and the subconscious. I would like to take the time to clarify this last sentence. Some theoretical approaches in social sciences investigate the human being from a specific perspective, shedding light on only some aspects of his/her life and essentializing the subject of research (i.e., the 'colonizer' in Algeria, Morocco or Libya). But that specific 'colonizer', who lived under a specific colonial dominion, had a name, a body and a story. Furthermore, that person was not only a 'colonizer': her/his biography is a complex one to grasp. In his famous book The Cheese and the Worms, Carlo Ginzburg highlights the complexity of human mentality: the volume problematizes the beliefs and imagination of Menocchio, a miller from a small town in the north of Italy, in the second half of the sixteenth century (GINZBURG, 1976). Ginzburg analysed his story through sources produced by the Inquisition, between coherence and contradictions. When I write, above, that it is difficult to reset or nullify the positionality from which we approach a study, I mean that scholars usually situate a story in a specific context (the migration context for 'migrant' people, for example). Consequently, various methods are used to approach and find possible interviewees: following the migration flows in a specific country or city; mapping the diaspora's meeting places; tracing a genealogy of migrant communities; asking other scholars or friends to share useful contacts. All this means elaborating, deliberately or involuntarily, a framework in which 
we, as scholars, plan to build up our research project (e.g., a migrant person as part of a migrant community in a specific city). But not all people who have migrated want to live in that context (e.g., second-generation young people who turn their backs on the migrant community); consequently, some of them may remain invisible to the scholar's gaze. I usually use this method: after some preliminary research, I spend time in the social contexts where I plan to collect interviews. I try to meet people, to talk with them, to learn about their lives. But, first of all, I try to emphasize relationships, setting aside the goals of the research: people are my first priority.

During the interview, first, and the interpretive process, thereafter, it is important to take into account a wider range of aspects in which the subject is involved: the scholar must move from the identification of the subject(s) which was planned during the design/drafting of the research - to the investigation on the subjectivity. For this reason, each interviewee should be considered representative also of other cases of people who had the same life trajectory, as explained by Luisa Passerini in Torino operaia e fascismo (1984). This approach sheds light on different subjectivities and life stories; on various uses of memory to elaborate a self and collective identity; on the movement of bodies and different positionalities in the same social context.

In the following pages, I would like to discuss some reflections arising from my oral historical and (auto)biographical research in collecting interviews with people from the Horn of Africa; the problematic question of silence as a source that has to be interpreted; and the role of voice in the construction of a historical narrative. Finally, my conclusions will examine the practice of empathy as a way to approach the unknown, unintelligible or obscure in my research practice.

\section{Silence beyond borders}

We are talking about a specific silence. It is not the silence recounted in Gianfranco Rosi's 2016 film Fuocoammare ('Fire at Sea') that results from the wait for migrants to arrive in Lampedusa. That silence, like each successive sign of the apocalypse, can be interpreted as the incompatible and irreconcilable relationship between two cultural contexts (De Martino 2002). That silence is evidence of the impossibility and inability to translate and (re)codify the Other. And this last word has at least three meanings: Other in the psychoanalytic perspective, as a place where meaning is elaborated; Other as the cultural context assigned to a specific subject; Other as an incarnated meaning along a specific positionality (race, gender, colour, etc.). In each of these interpretations, the Other is a border between the Self and the rest of the world. In this sense, silence marks a space of detachment between one subjectivity, which is central, and Other subjects, who are subjectivized in order to produce meanings that are useful for empowering the first narrative: in this sense, the Other is the field where the narrative defines the Self in opposition or for identification (BADIOU, 1982; LÈVINAS, 1980; SAID, 1978, 1993).

The silence I would like to talk about is not located on the other shore of the Mediterranean, in the illegal detention camps or jails managed by Libyan irregular troops. That silence I am talking about is produced by people - usually called simply 'migrants' - as a consequence of a combination of power imbalances in place (the agreement between Italy and the temporary Libyan government in Tripoli, the military engagements forecast by the EU mission's Operation Sophia, etc.). The silence, in that case, denies a space where, without any euphemism, black people, most of them coming from sub-Saharan countries, are 
not considered as human beings and are treated as slaves (BALIBAR, 2004; DANEWID, 2017).

The silence I am interested in takes place in Europe. I have experienced this silence indirectly while interviewing several people in Italy. Sometimes, as in the case of Shukri, a 23-year-old Somali woman, silence is the consequence of remembering the trip from Zuwarah to Lampedusa. 'I was frightened because of the sea. I hadn't crossed a sea before. I am not able to swim.' In another story, by Mohamed, a 32-year-old Somali man, silence represented the impossibility of telling the story of his journey from Tripoli to Lampedusa. He understood my question about the Mediterranean crossing but he was not fluent in English. I asked him to draw a map of this journey. He spoke in Somali during his tale of the trajectory from Mogadishu to Europe. I was able to understand only a few words in the Somali language such as the names of places: Hargeisa, Khartoum, Sahara and Tripoli. The map was a mass of lines, without any sense of the political geography. Or, more appropriately, that was my first impression. I did not pay attention to the relationship between the act of drawing the map and silence. Only after collecting several interviews and maps did I go back to that topic. As a result of that reconsideration, my interpretation of silence changed: I realized there was another possible reason for Mohamed's representation of the map. I revisited the oral sources and re-actualized their meanings from an intersubjective point of view. Mohamed's life and body were objectivized under my gaze and hearing, in the sense that he was not a subject but an object of the territory he crossed, of its narratives and devices (borders, jails, illegal alien camps, etc.). He did not move; he was moved. There was a close connection between the impossibility of talking a specific language - concerning the 'governmentality' (Foucault 2007) of the migration path - and his way of representing his experience. That silence arose from a sense of alienation and, perhaps, embarrassment as a result of my request for him to produce a map: a performance that turned his positionality about that particular way of entering Europe upside-down.

I remember two other typologies of silence. Bologna, winter 2014. I got out of the car. All around me were public housing units. After passing through a gate, I arrived at a courtyard. Yassim, a Nigerian man, welcomed me and asked me to sit in a plastic chair from Ikea. While I waited, I heard, on my left, African music coming from inside my interviewee's house; on my right, a Sicilian man scolding his child for getting a bad grade at school. I thought those very different words had several things in common, and that the enclosure that divided the space was a metaphor for racism, for two different points of view of a space and an experience which should, on the contrary, connect people. At that point, Sheila arrived. She was an Eritrean woman; at the time of the interview, she was 32. Her journey was the same as Mohamed's and Shukri's. But she was not able to talk about the period she spent in Libya and the beginning of her stay in Italy. I immediately realized the reason for the silence: something happened to her on both sides of the Mediterranean. There were no signs indicating this interpretation of her silence: her way of being quiet was the same as several other people's. Nevertheless, I understood and decided to go ahead with the interview, changing topics and starting to talk about her family. After the interview and off mike, she confessed to me that she was subjected to violence in Libya and sexual abuse in Italy; she was forced to 'work' - she used the Italian word lavorare - on the street. She told me, 'Tell this part of the story too, but I don't want to be recorded.' On the way back 
home, I thought back to Sheila and her words. When I had the transcription of the interview in my hands, I opted to interpret her silence as probably motivated by anxiety about leaving evidence of what happened to her. But if this explanation was possible, why had she asked me to include the part dealing with violence and rape? I got the answer the second time I met her. She said to me, 'I was not ready to talk in public, to everyone, about my past. But you, you can do it, you will find the right words.' In this case, silence was a third position between the impossibility of talking and telling a story: it is a sort of strategy for making a story visible without talking about it; it is a change of position - and consequently a movement of sense/meaning shift - between interviewee and interviewer; it is an emotional border of the representativeness - I use this word in the sense of possibility/willingness to represent a memory of the past - I experienced together with her.

Hence, silence is an active part of the interview and the intersubjective process. After the inclusion of silence among the possible sources the scholar has to investigate, one can add that there is no one typology of silence. As in the three cases mentioned above, silence has relevance in the construction of meaning during the interview and in the interpretation of oral sources. We can consider silence as a 'permeable area' where subjectivities can meet. Therefore, silence is more than a sign of absence of voice: on the contrary, it can also be a space of mediation and representation elaborated in relation to the subjectivities involved. In Shukri's narrative, silence was the evidence of a trauma, a strong emotion on remembering the journey. Conversely, for Mohamed silence was the expression of a geography oriented on other codices and points of reference. Finally, Sheila used silence strategically, to transmit a feeling - through her narrative - escaping from the formalized modalities to denounce violence and its consequences in terms of visibility in the public sphere.

\section{Angela/Malaika, an Italo-Somali woman in Milan}

In this section, I would like to focus my attention on one identity - like others that appeared during my fieldwork in collecting oral interviews - which I have defined as 'out of place' (PUWAR, 2004). Why? Because, for several reasons, this identity crosses borders and categories (race, gender, colour, etc.): as we will discover in the next few paragraphs, Angela/ Malaika reinvented herself outside these categories. The concept of identity played an important role during the production of the drawing I asked each interviewee to make at the end of our meetings. We, the B.A.B.E. research team,' called this artefact a 'map', but it would be useful to think of it as an interview's geography of emotions. Our intention was to ask to the interviewee to represent various typologies of memories evoked during the interview. The representation of cultural memory takes several forms and representations on the page, most of which are determined by feelings and emotions. For an appropriate interpretation of the map, we need to combine this source with interview transcripts. In the following paragraphs, I will describe one of these visual sources.

I met Angela in a bar, not far from the Milan Central Railway Station. She was born in Moga-

1 B.A.B.E. is the acronym of Bodies Across Borders: Oral and Visual Memory in Europe and Beyond. This ERC-funded project started in 2014 and was headed by Professor Luisa Passerini. The project, which was based at the European University Institute, proposes to study intercultural connections in contemporary Europe, engaging both native and 'new' Europeans. These connections are woven through the faculties of embodied subjects - memory, visuality and mobility - and concern the movement of people, ideas and images across the borders of European nation-states, with a focus on Italy and the Netherlands. For more information, please visit the B.A.B.E. website: https:// babe.eui.eu/. 
dishu and now lives in Milan. She was 52 at the time of the interview, in October 2015. From the outset, she told me that her neighbourhood in Somalia was the land of Italo-Somali people. And immediately after that, she added, 'my mother was Somali, but my father was Italian'. I remember that 'but', which sounded like an attempt to dislocate herself in the two different contexts. She then said that the Italo-Somalis were a small tribe. I was struck by her use of 'tribe': although we were outside Somalia, she was reproducing an essentially Somali way of classifying people based on their ethnic and clan membership. When we talked about the colonial period, the theme of the Italo-Somalis was still important: 'Italians had that small vice... and we were all Italo-Somali.' 'All', in this case, is the sign of a colonial power that was able to control people's bodies and, through them, the entire Somali imagined community. When she said 'all', it upset me very much. I understood later that my feelings were not only about Italy's colonial past. Angela was producing an emotional geography, working simultaneously on the past and the present. My 'past' and 'present', I should note: in her view, colonial past and postcolonial present inhabited the same place in memory. After discussing colonialism, she told me about her present life in Milan. She loved Milan and all of the opportunities it offered. But she pointed out, in the final part of the interview, that she - like other Italo-Somali people - is neither white nor black.

She represented the Italo-Somali concept in her 'map'. Her emotional geography included anger about conditions in Somalia, happiness about being in Italy, and nostalgia because she could not go back home. In the 'map', one can see a circle; she used two colours - brown and black - and she drew an ' $S$ ' between them. She wrote Malaika/Angela in the centre. Malaika ('angel') is the Arabic name she used in Somalia; Angela is its Italian equivalent. Then she explained that, for her, the circle also represents an egg: 'something which can protect me', she said. 'The white part is the Somalia in me; the black part is the Italy', she went on. I was struck by her reversal of the colours: 'Don't you mean the white is Italy and the black is Somalia?' She confirmed that she meant what she had said because - in her words - "I am always out of place, as all Italo-Somalis were and are out of place, in the present, in the past, when Italians ruled in Somalia.' Then she added that 'the future belongs to the pallidi'. The Italian word pallidi cannot be translated simply as 'pale-skinned'. From a medical point of view, the word describes people who are sick (i.e., it is equivalent to pallid or sickly). However, I understood that she was not using that interpretation because of the silence before her sentence. She stopped. After a few seconds, I looked down because I was embarrassed, not because of the colour of my skin but because of the situation she and other Italo-Somali people faced. I think she saw how I felt and she began to talk again in order to put an end to that awkward silence. To me, this part of the interview was the sign of our meeting. She said, 'if you are coloured, you have a place, always, here, in Somalia, in every part of the world.' 'Some people call me meticcia ['mixed race'], others nera or negra ['black' or 'negro']. But I don't want to obey these classifications. I am Angela and Malaika at the same time. Why not? This means being Italo-Somali. It is not a sort of place in between, between Africa and Europe, Somalia and Italy, between past and present; it is a game of strategies and I, we - as Italo-Somalis - tip the odds in our favour.' We were silent for several seconds. Finally, she said, 'I am not half of something, half black, half Italian, half woman. I am a unique subject, a sort of unity, which is as complete as the egg in my drawing.' 
Figure 1 - Angela/Malaika's map

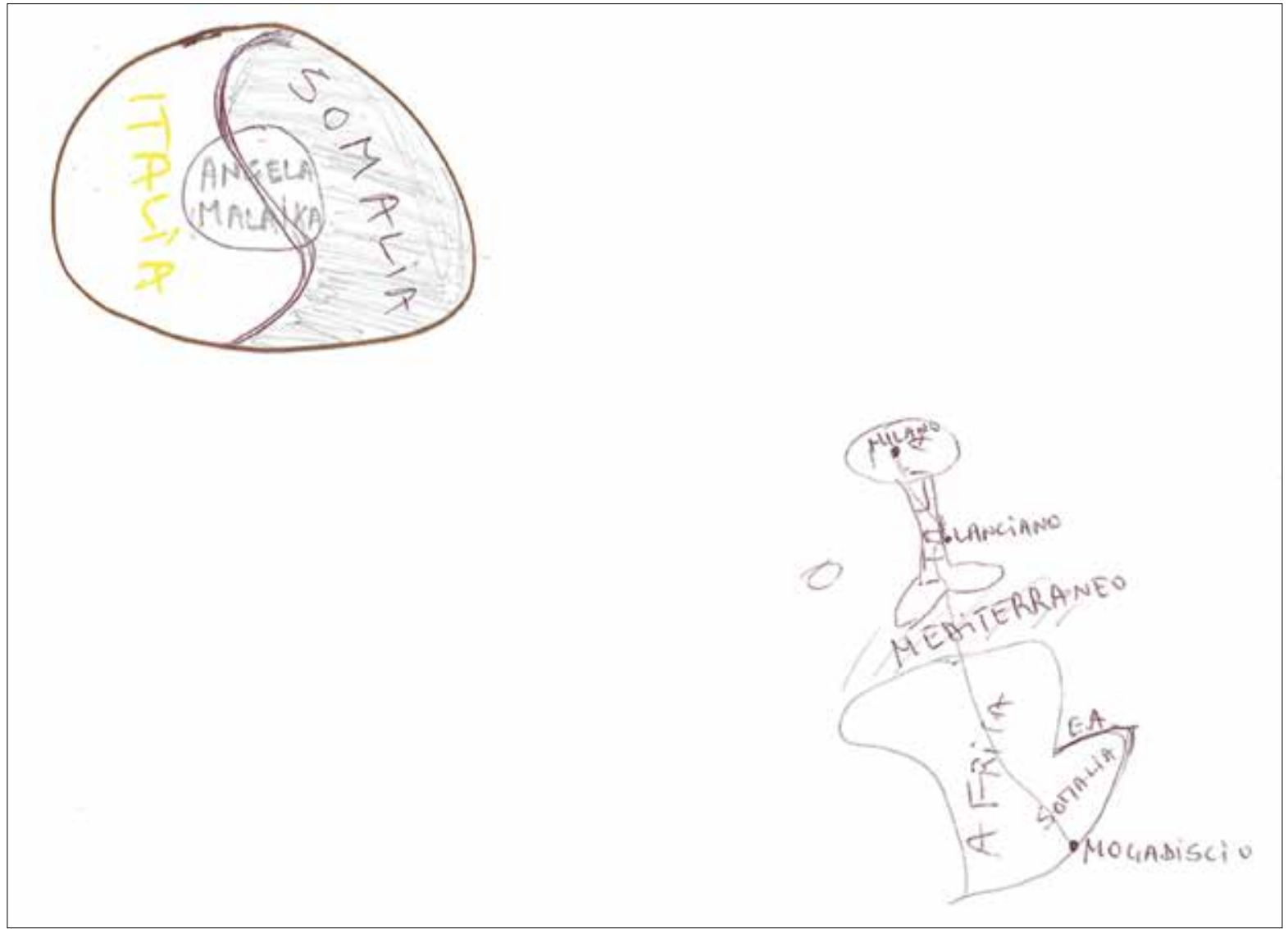

\section{Empathy as practice}

In this concluding section, I would like to describe my approach to conducting biographical interviews with migrants. My goal was to map the mobility of their memory - and their memory of mobility - before, during and after the migratory trajectory. This focus on narratives concerning both personal and collective stories was limited by the need to record each interview at one specific point in time. I was unable to interview people outside Europe, in the Horn of Africa or while they travelled to Europe. I was uneasy about presuming to talk about something that I had previously experienced only by reading books and articles, watching documentaries and talking with friends from Somalia, Ethiopia and Eritrea.

After the preliminary phase of the interview, during which my interlocutors and I were getting to know each other, there were always two subjectivities involved in the attempt to ana- lyse memory. This meant two different points of view: the interviewee's gaze was focused on a lived bodily experience; as several interviewees told me off the record, they had always previously told their stories in the same way. This was because many Ethiopian, Eritrean and Somali people apply for refugee status or are asylum seekers, after they get to Italy. During the meeting with the institutional commission which has to review and decide on their application, they have to talk about their journey, with detailed dates and references to specific cities and places. This narrative - which is constructed before the meeting with the specific goal of obtaining a permanent citizenship in Italy/Europe - is also used with other Italian people, in order to present a canonical representation of the past. On the contrary, for many of the people I met, the interview was an opportunity for them to revitalize abandoned 
memories. My focus, on the other hand, was on reconstructing the story and collecting memory fragments. The interviewees sought to shed light on a canonical representation, expressing various social desires they felt (to apply for refugee status, to acquire a social place in the migrant community in Europe, to fit into the urban context, etc.). I peered into a dark past that I could only piece together from my own perspective. As we went ever deeper in exploring each interviewee's memory, our different views became part of the same investigation; still, they never converged to become a single gaze.

We expressed our participation in the same research project - albeit with different trajectories and points of departure - by sharing our emotions. I often found that the interviewees' stories of violence, imprisonment and shipwreck affected my energy and morale: the day before the interview, I usually had no energy. But when I started to produce the transcriptions of the interviews, I realized that we were all connected by our shared intention to investigate their past. Given that my subjectivity is connected with my work, my approach to this research has theoretical implications. I conceive of the practice of empathy as a dialogue between subjectivities: those of the interviewer, the interviewee and other people involved in the story. Intersubjectivity represents a connection among several voices, as well as with the 'place of meaning' where individual memories and a group's story are renegotiated simultaneously. Both oral and visual narratives inhabit this space. Striving to be empathetic with my interlocutors means being willing and able to track the movements of memory as we remember it together. This can only be done if the interviewee's emotions reverberate into the interviewer's subjectivity; if our shared humanity builds up a space of learning and understanding from our differences.
According to Kathleen Blee (1993), 'the ability of oral history to provide new and accurate insights into the lives and understandings of ordinary people in the past depends on a crucial approach to oral evidence and the process of interviewing' (1993, p. 334). If what an informant does or does not say is 'a fact' just as much as what 'really happened' (THOMPSON, 1988), the researcher must move from the text (such as the literature on the diaspora from the Horn of Africa) to the world, and contact with another subjectivity (Salazar, 1991). This shifting of viewpoints is possible only with an act of abandonment, which decreases the tension between the occasion of the meeting with the informant and the goals and expectations of the interview.

In an enlightening passage, Blee (1993) reflects on her experience during her research about the stories of the Ku Klux Klan. She writes, 'the evidence of oral history is embedded not only in narrative accounts but also in the process of interviewing' (p. 336). Blee's hypothesis is that it is sometimes possible to work to create a connection between the two subjectivities. We can find traces of this approach in Luisa Passerini's (1984) and Alessandro Portelli's (1999) research on Fascism, in the act of declaring a dissociation or distance from the regime, or, on the contrary, in affirming solidarity with the anti-Nazi Resistance. This way of conducting an interview is in opposition to the tradition according to which it is important to maintain distance and remain neutral with the interviewee. In Blee's approach, meanings move between the researcher and the informant and both subjectivities are able to ask, and answer, questions.

Hence, an interview is a reciprocal exchange. From an intersubjective perspective, it is possible to state that the production of the source - historically speaking - is more than the interaction between two subjectivities. 
Trying to conduct an interview with empathy means feeling the estrangement, as a result of the loss of reference points in the dialogue with another voice, as a unique opportunity to be led to unforeseen horizons of memory. In this attempt, the body is the real place where it is possible to experience contact with the other subjectivity, beyond words. When silence arises, for example, it is possible to confer several different meanings on the act of remaining silent. Silence is not only an absence of voice; silence can be another way of talking. Only through empathy is it possible to try to attribute interpretations to silence. Empathy, then, is an effective practice for calling categories and attributions of interpretations into question that, as researchers, we are usually unaware of: 'I am Angela and Malaika at the same time. Why not?'

\section{References}

ARMITAGE, Susan; BERGER GLUCK, Sherna. Reflections on women's oral history: An exchange. Frontiers: A Journal of Women Studies, v. 19, n. 3, p. 1-11, 1998.

BADIOU, Alain. Théorie du sujet. Paris: Seuil, 1982.

BALIBAR, Etienne. Europe as borderland. Alexander von Humboldt Lecture. Human Geography, University of Nijmegen, November 10, p. 1-11, 2004.

BENJAMIN, Walter. The Arcades Project. Cambridge, MA: Harvard University Press, 1999.

BLEE, Kathleen. Evidence, empathy and ethics. Lesson from the oral histories of the Klan. Journal of American History, v. 80, n. 2, p. 596-606,1993.

BRIGHTON, Ourstory. Daring hearts: lesbian and gay lives of 50s and 60s Brighton. Brighton: Queenspark Books, 1992.

BROWN, Gavin. Listening to queer maps of the city: gay men's narratives of pleasure and danger in London's East End. Oral History, v. 29, n. 1, p. 48-61, 2001.

DANEWID, Ida. White innocence in the black mediterranean: hospitality and the erasure of history.
Third World Quarterly, v. 38, n. 7, p. 1674-1689, 2017.

DE MARTINO, Ernesto. La fine del mondo. Contributo all'analisi delle apocalissi culturali. In: GALLINI, C.; MASSENZIO, M. (Eds.). La fine del mondo, Turin: Einaudi, 2002. p. 1-370.

FOUCAULT, Michel. Security, territory, population: lectures at the Collège de France 1977-1978. M. Senellart, editor; G. Burchell, translator. Basingstoke: Palgrave Macmillan, 2007.

FRISCH, Michael. A shared authority: essays on the craft and meaning of oral and public history. Albany, NY: Suny Press, 1991.

FRISCH, Michael. Three dimensions and more: oral history beyond the paradoxes of method. In: HESSE-BIBER, Sharlene; LEAVY, Patricia. (Eds.). The handbook of emergent methods. New York: Guilford Publications, 2010. p. 75-94.

GINZBURG, Carlo. Il formaggio e i vermi. Turin: Einaudi, 1976.

GLUCK, Sherna Berger. Women's words: the feminist practice of oral history. Routledge. New York: Einaudi, 1991.

GLUCK, Sherna Berger. The representation of politics and the politics of representation: historicizing palestinian women's narratives. In: SCHNEIDER, William. (Ed.). Living with stories: telling, re-telling and remembering. Logan, UT: Utah State University, 2006. p. 4-16.

GLUCK, Sherna Berger. Has feminist oral history lost its radical/subversive edge? Oral History, v. 39, n. 2, p. 63-72, 2011.

GRELE, Ronald J. Can anyone over thirty be trusted? A friendly critique of oral history. In: GRELE, Ronald J. (Ed.). Envelopes of sound: the art of oral history. Chicago: Precedent Publishing, 1985. p. 88-113.

GRELE, Ronald J. Subjectivity and multiculturalism. In: GRELE, Ronald J. (Ed.). Oral history, international annual of oral history. Westport, CT: Greenwood Press, 1990. p. 137-145.

HALEY, Alex. The autobiography of Malcolm X. New York: Grove Press, 1965. 
JENNINGS, Rebecca. Lesbian voices: the Hall Carpenter Oral History Archive and post-war British lesbian history. Sexualities, v. 7, n. 4, p. 430-445, 2004.

LAMONT, William. (Ed.). Historical controversies and historians. London: UCL Press, 1998.

LÈVINAS, Emmanuel. Le temps et l'autre. Saint-Clément-de-Rivière, France: Fata Morgana, 1980.

LIDDINGTON, Jill. Rediscovering suffrage history. History Workshop Journal, v. 4, p. 192-201, 1977.

LOMAS, Clare. Men don't wear velvet you know! Fashionable gay masculinity and the shopping experience. Oral History, v. 35, n. 1, p. 82-90, 2007.

MEZZADRA, Sandro. Diritto di fuga. Migrazioni, cittadinanza, globalizzazione. Verona: Ombre Corte, 2001.

PASSERINI, Luisa. On the use and abuse of oral history. In: PASSERINI, Luisa. (Ed.). Storia orale: vita quotidiana e cultura materiale delle classi subalterne. Turin: Rosenberg \& Sellier, 1978. p. 70-88.

PASSERINI, Luisa. Oral history and people's culture. History Workshop, n. 13, p. 88-98, 1979a.

PASSERINI, Luisa. Work Ideology and consensus under Italian fascism. History Workshop, n. 8, p. 84-92, 1979b.

PASSERINI, Luisa. Torino operaia e fascismo: una storia orale. Rome and Bari: Laterza, 1984.
PASSERINI, Luisa. Memoria e utopia. Il primato dell'intersoggettività. Turin: Bollati Boringhieri, 2003.

PERKIN, Harold. Social History in Britain. Journal of Social History, v. 10, n. 2, p. 129-143, 1976.

PORTELLI, Alessandro. L'ordine è già stato eseguito. Roma, le Fosse Ardeatine, la memoria. Rome: Donzelli, 1999.

PUWAR, Nirmal. Space invaders. Race, gender and bodies out of place. New York: Berg Publishers, 2004.

SAID, Edward. Orientalism. New York: Penguin, 1978.

SAID, Edward. Culture and imperialism. New York: Chatto \& Windus, 1993.

SALAZAR, Claudia. A third world women's text: between the politics of criticism and cultural politiCs. In: BERGER GLUCK, Shema; PATAI, Daphne. (Eds.). Women's Words. New York: Palgrave, 1991. p. 93-106.

THOMPSON, Paul. The voice of the past: oral history. Oxford: Oxford University Press, 1988.

Recebido em: 10.01 .2018 Aprovado em: 04.03.2018

Gabriele Proglio é investigador de pós-doutoramento (FCT) do Centre for Social Studies, University of Coimbra. e-mail: gabrieleproglio@gmail.com; gabrieleproglio@ces.uc.pt

Centro de Estudos Sociais (Coimbra, Alta). Colégio de S. Jerónimo. Apartado 3087 3000-995 Coimbra, Portugal. Tel +351 239855 570/80 Cel +39 3939009380 